\title{
PERAN MODAL PSIKOLOGIS DAN DUKUNGAN ORGANISASI TERHADAP KESIAPAN KERJA MAHASISWA INTERNSHIP
}

\author{
Jessica Chandhika dan Kiky D.H. Saraswati \\ ${ }^{1}$ Program Studi Psikologi, Universitas Tarumanagara Jakarta \\ Email:jessica@fpsi.untar.ac.id \\ ${ }^{2}{ }^{1}$ Program Studi Psikologi, Universitas Tarumanagara Jakarta \\ Email: kikys@Fpsi.untar.ac.id
}

Masuk :10-04-2019, revisi: 12-09-2019, diterima untuk diterbitkan : 12-09-2019

\begin{abstract}
ABSTRAK
Penambahan peluang kerja tidak sebanding dengan peningkatan jumlah tenaga kerja dari waktu ke waktu. Untuk mendapatkan tenaga kerja yang berkualitas, perusahaan biasanya menggunakan sistem seleksi yang ketat, sehingga dapat membedakan kesiapan para kandidat, utamanya yang baru saja menyelesaikan pendidikannya untuk bekerja secara formal. Kesiapan Kerja adalah dimilikinya keahlian, pengetahuan, dan sikap dasar, serta pemahaman praktis yang memungkinkan lulusan memberikan kontribusi produktif bagi tujuan organisasi. Kesiapan Kerja dapat dipengaruhi oleh dua faktor, yaitu faktor internal dan eksternal. Salah satu faktor internal yang berperan adalah Modal Psikologis. Modal Psikologis adalah keadaan psikologis yang positif pada diri individu yang ditandai dengan selfefficacy, optimisme, harapan, dan resiliensi. Sedangkan salah satu faktor eksternal yang berperan adalah Dukungan Organisasi, yaitu persepsi karyawan terhadap sejauh mana organisasi memberi nilai positif terhadap kontribusi mereka serta peduli terhadap kesejahteraan mereka. Dukungan Organisasi telah ditemukan memiliki konsekuensi penting terhadap kinerja dan kesejahteraan karyawan. Suatu organisasi yang siap dalam memberikan imbalan terhadap usaha kerja karyawan dan memenuhi kebutuhan sosio-emosional akan meningkatkan komitmen karyawan dalam bekerja. Penelitian ini adalah penelitian kuantitatif. Data diambil dengan menyebarkan kuesioner Work Readiness, Survey of Perceived Organizational Support, dan Psychological Capital pada mahasiswa peserta program internship di Perguruan Tinggi X, Jakarta. Hasil penelitian ini menunjukkan bahwa Modal Psikologis dan Dukungan Organisasi memiliki kontribusi yang signifikan terhadap Kesiapan Kerja ( $F=14.349$, p< 0,000).
\end{abstract}

Kata Kunci: Kesiapan Kerja, Modal Psikologis, Dukungan Organisasi, Internship, Mahasiswa

\section{ABSTRACT}

The increase in employment opportunities is not proportional to the increase in the number of workers over time. To acquire high quality workforce, companies use a strict selection system in order to distinguish the readiness of candidates, especially those who have just completed their education to work formally. Work Readiness is the possession of basic skills, knowledge and attitudes, as well as practical understanding that enable graduates to productively contribute to organizational goals. Work Readiness can be influenced by two factors, namely internal and external factors. One such internal factor is Psychological Capital. Psychological Capital is a positive psychological state within an individual that is characterized by self-efficacy, optimism, hope, and resilience. Meanwhile, one of the external factors is Organizational Support that is employee perception of the extent to which the organization gives a positive value to their contribution and care for their well-being. Organizational support has been found to possess important consequences on employee performance and welfare. An organization that is ready to reward employees' work effort and meet their socio-emotional needs will increase employees' work commitment. This research is a quantitative research. Data were taken by distributing the Work Readiness, Survey of Perceived Organizational Support, and Psychological Capital questionnaires to students participating in the internship program at X University, Jakarta. The result of this study indicates that Psychological Capital and Organizational Support significantly contribute to Work Readiness ( $F=14,349, p<0,000)$.

Keywords: Work Readiness, Psychological Capital, Organizational Support, Internship, Students

\section{PENDAHULUAN}

Bekerja merupakan hal yang paling lama dilakukan oleh manusia di usia produktif mereka. Dunia kerja tentunya berbeda dengan dunia pada masa kuliah di perguruan tinggi. Pada umumnya lulusan 
perguruan tinggi akan terjun ke dunia kerja yang sesuai dengan bidang dan minat mereka. Namun, jumlah lapangan pekerjaan yang tersedia tidak sebanding dengan ketersediaan tenaga kerja yang terus saja bertambah. Hal ini membuat perusahan akan melakukan seleksi terhadap lulusan baru dan memilih lulusan yang sudah siap kerja agar mudah beradaptasi di tempat kerjanya. Akibat dari sikap perusahaan ini adalah sulitnya lulusan untuk diserap di dunia kerja.

Data Badan Pusat Statistik menunjukkan bahwa jumlah pengangguran di Indonesia pada bulan Agustus 2018 ada sebanyak 5,34\% dari total penduduk Indonesia. Hal tersebut menunjukkan bahwa dari total penduduk Indonesia, terdapat sekitar 7 juta orang yang tidak memiliki pekerjaan. Untuk menanggapi hal ini, institusi pendidikan perguruan tinggi sebaiknya turut ambil bagian dalam mengantisipasi bertambahnya jumlah mahasiswa yang tidak memperoleh pekerjaan setelah lulus kuliah dengan meningkatkan Kesiapan Kerja lulusannya. Salah satu langkah yang diambil oleh institusi pendidikan adalah dengan mengimplementasikan program internship dalam kurikulum di program studinya. Menurut Undang Undang No. 13 tahun 2003 tentang Ketenagakerjaan, internship atau pemagangan adalah sistem pelatihan kerja terpadu dengan bekerja secara langsung di bawah bimbingan dan pengawasan instruktur atau pekerja/buruh yang lebih berpengalaman, dalam proses produksi barang dan/atau jasa di perusahaan, dalam rangka menguasai keterampilan tertentu (dikutip dalamhttp://www.kemenperin.go.id/kompetensi/UU_13_2003.pdf). Dengan adanya program internship, mahasiswa tingkat akhir diharapkan sudah terbiasa dengan dunia kerja, sehingga akan mempermudah proses adaptasi dengan lingkungan kerja nantinya. Atau dengan kata lain, mereka sudah lebih siap untuk bekerja.

Dari penelitian yang dilakukan oleh Sampson, Peterson, Reardon, \& Lenz (2000) menemukan bahwa Kesiapan Kerja merupakan salah satu faktor yang memberikan pengaruh yang signifikan bagi perencanaan karir dan pengambilan keputusan lulusan terhadap karir yang akan mereka tempuh. Kesiapan Kerja membuat lulusan baru memiliki wawasan yang lebih luas, sehingga pada akhirnya mereka memilliki kesempatan yang lebih besar untuk masuk ke dunia kerja. Kesiapan Kerja sendiri menurut Cabellero dan Walker (2010) adalah persepsi lulusan terhadap sikap dan atribut yang dibutuhkan agar berhasil di tempat kerja. Hal yang sama dinyatakan oleh Mason, Williams, dan Cranmer (2009) bahwa orang yang memiliki Kesiapan Kerja adalah orang yang memiliki keahlian, pengetahuan, dan sikap dasar, serta pemahaman praktis yang memungkinkan orang tersebut untuk bekerja secara produktif dan berusaha mencapai tujuan organisasi.

Menurut Winkel dan Hastuti (2006), Kesiapan Kerja dapat dipengaruhi oleh dua faktor, yaitu faktor internal dan eksternal. Faktor internal penting yang dapat mempeganruhi Kesiapan Kerja terdiri dari delapan aspek yakni career self-management, cultural competence, self-efficacy, career resilience, sociability, entrepreneurial orientation, proactivity, dan emotional literacy (Coetzee, 2014). Faktor eksternal dapat dilihat dari lingkungan yang mendukung seperti keluarga, teman dan organisasi itu sendiri. Self efficacy dan resiliensi adalah dua dimensi dari Modal Psikologis. Dimensi lain dari Modal Psikologis adalah optimisme dan harapan (Luthans, 2015). Modal Psikologis merupakan faktor inti dari psikologi positif, sehingga membuat manusia mengembangkan dirinya sendiri. Hal ini membuat Modal Psikologis akan memberikan pengaruh terhadap kinerja karyawan dan keinginan untuk bekerja.

Selain faktor internal di atas, salah satu faktor eksternal yang dapat memengaruhi Kesiapan Kerja lulusan, yaitu Dukungan Organisasi. Dukungan Organisasi merupakan persepsi karyawan mengenai sejauh mana organisasi menilai kontribusi mereka dan peduli terhadap kesejahteraan mereka (Eisenberger, et.al., 1986). Perlakuan yang diperoleh karyawan baik menguntungkan 
maupun tidak menguntungkan akan menentukan penilaian karyawan akan Dukungan Organisasi terhadap usaha mereka (Kurtessis, et. al., 2015). Jika seorang karyawan memperoleh keuntungan dari Dukungan Organisasi maka karyawan tersebut akan merasa berkewajiban untuk membantu organisasi mencapai tujuannya sehingga pada akhirnya hal ini juga akan membawa keuntungan kepada organisasi. Dari hasil penelitian yang dilakukan oleh Neves dan Eisenberger (2012) ditemukan bahwa perlakuan supervisor merupakan hal yang dilihat karyawan dalam menentukan besarnya Dukungan Organisasi. Penelitian ini juga menemukan bahwa keterbukaan komunikasi antara manajemen dan karyawan adalah cara yang efektif untuk meningkatkan kinerja karyawan. Berdasarkan pemaparan di atas, peneliti menyimpulkan pentingnya untuk mengetahui peran Modal Psikologis dan Dukungan Organisasi terhadap Kesiapan Kerja mahasiswa peserta program internship di Perguruan Tinggi X.

\section{LANDASAN TEORI}

Menurut Mason, Williams, dan Cranmer (2009), Kesiapan Kerja merupakan keahlian, keterampilan pengetahuan, dan sikap dasar, serta pemahaman praktis yang dimiliki seseorang. Adanya keterampilan, pengetahuan dan sikap dasar ini pada mahasiswa tingkat akhir akan sangat mendukung untuk mencapai tujuan organisasi yang sudah ditetapkan pada saat memasuki dunia kerja. Cabellero dan Walker (2010) pun mendefinisikan Kesiapan Kerja sebagai gambaran persepsi lulusan terhadap sikap dan atribut yang dibutuhkan agar berhasil di tempat kerja.

Kesiapan Kerja mengandung dua pengertian, yakni keadaan siap siaga untuk menanggapi, mengembangkan dan mempraktikkan keahlian serta pengetahuan yang dimiliki (Chaplin, 2011). Hal yang serupa dinyatakan oleh Agusta (2015) bahwa Kesiapan Kerja merupakan kapasitas seseorang dalam meningkatkan kemampuan bekerjanya yang terdiri dari ilmu pengetahuan dan keahlian serta sikap seseorang tersebut. Sedangkan Andrew (dalam Saputro \& Suseno, 2009) menyatakan bahwa Kesiapan Kerja merupakan kapabilitas seseorang dalam meningkatkan kemampuan bekerjanya, yang terdiri dari ilmu pengetahuan, keahlian serta sikap seseorang tersebut.

Menurut Brady (2010), Kesiapan Kerja terdiri dari 6 aspek, yakni tanggung jawab, fleksibilitas, keterampilan, komunikasi, cara pandang terhadap diri sendiri, serta kesehatan dan keselamatan kerja. Tanggung jawab nampak dalam perilaku karyawan untuk selalu datang tepat waktu dan tidak pulang lebih awal dari jam kerja yang sudah ditetapkan, berusaha mematuhi peraturan perusahaan yang sudah ditetapkan, bekerja sesuai dengan kualitas standar perusahaan dan berusaha untuk menjaga rahasia perusahaan. Fleksibilitas bisa dilihat dari kemampuan karyawan untuk beradaptasi terjadap perubahan dan tuntutan, memiliki mobilitas yang tinggi, serta tidak mempermasalahkan jika ada perubahan jadwal kerja, tugas, dan lokasi kerja. Keterampilan nampak dalam kemampuan dan keterampilan yang dimiliki oleh karyawan untuk digunakan di tempat kerja serta bersedia untuk mengembangkan keterampilan yang sudah dimiliki untuk menunjang pekerjaan mereka.

Seorang lulusan baru harus menunjukkan kemampuan komunikasi yang baik di mana mereka mampu untuk menjalin hubungan interpersonal dengan atasan, rekan dan bawahan di tempat kerja, termasuk menerima instruksi, meminta bantuan, serta menerima umpan balik dan kritik dari orang lain. Cara pandang terhadap diri sendiri terlihat dari keyakinan mereka terhadap diri sendiri dan pekerjaan. Sedangkan kesehatan dan keselamatan kerja adalah sejauh mana mereka mengelola kebersihan pribadi dan menjaga kesehatan fisik dan psikis, serta menggunakan peralatan kerja sesuai dengan prosedur pemakaiannya. 
Penelitian yang dilakukan oleh Bandaranaike dan Willison (2015) menunjukkan bahwa tidak ada perbedaan kemampuan kognitif dan afektif antara orang yang sudah pernah bekerja dengan yang belum pernah bekerja. Penelitian yang sama juga menunjukkan bahwa tidak ada perbedaan secara usia dan jenis kelamin dalam penggunaan kemampuan kognitif dan afektif dalam usaha untuk mencari kerja. Bandaranaike dan Willison (2015) menemukan bahwa ada perbedaan kemampuan kognitif yang digunakan oleh lulusan dari jurusan yang berbeda. Contohnya lulusan geologi lebih banyak menggunakan kemampuan identifikasi mineral pada bebatuan dan lulusan manajemen lebih mengembangkan kemampuan dalam merencanakan kegiatan.

Perilaku organisasi yang positif menekankan pentingnya hal-hal positif dalam bekerja dibandingkan menonjolkan sisi negatif. Hal ini membuat sumber daya manusia harus disikapi dan diolah secara positif terutama karena sumber daya manusia merupakan aset organisasi yang paling berharga. Salah satu pengembangan dari perilaku organisasi yang positif adalah Modal Psikologis. Menurut Luthans (2015), Modal Psikologis terdiri dari empat konstruk yaitu, self efficacy, harapan, optimisme, dan resiliensi. Self efficacy merupakan kepercayaan diri seseorang yang selalu berusaha untuk mencapai kesuksesan dalam menghadapi tugas yang sulit. Orang dengan self efficacy yang tinggi akan menetapkan tujuan yang tinggi dan tidak takut dalam mengerjakan pekerjaan yang sulit. Karakteristik lainnya adalah memandang hambatan sebagai tantangan yang harus dihadapi dan berusaha mencari solusi dari setiap hambatan yang ada. Mereka juga memiliki motivasi yang tinggi, berusaha untuk mencapai tujuan, serta tetap tekun dalam mencapai tujuan. Bahkan orang dengan self efficacy yang tinggi juga menciptakan tugas-tugas yang sulit untuk menantang diri mereka sendiri.

Harapan merupakan suatu kemampuan seseorang untuk menyadari bahwa ada tujuan dan mampu untuk memfokuskan diri dalam mencapai tujuan tersebut. Harapan sendiri merupakan motivasi positif yang timbul dari diri seseorang yang secara aktif dapat membawa seseorang untuk mencapai tujuan secara sukses. Jika ada hambatan untuk mencapai tersebut, orang yang memiliki harapan akan mencari jalan alternatif yang tetap dapat membawa mereka untuk mencapai tujuan yang sudah ditetapkan sebelumnya.

Optimisme ditandai adanya keyakinan positif di dalam diri bahwa dirinya dapat meraih kesuksesan, baik di saat ini maupun di masa depan. Optimisme membuat seseorang melihat segala peristiwa dengan pandangan positif dan paradigma bahwa semua hal akan berjalan dengan lancar dan hal positif akan terus-menerus terjadi. Dalam bekerja, karyawan yang memiliki optimisme akan merasa bahwa masukan yang diberikan oleh atasan adalah masukan yang berharga bagi dirinya dan akan bekerja lebih keras sehingga karyawan dapat berhasil.

Konstruk terakhir, resiliensi adalah kemampuan seseorang untuk bertahan dan menghadapi masalah dan kesulitan untuk mencapai kesuksesan. Resiliensi membuat seorang mahasiswa mampu untuk bangkit dari kegagalan dan mengambil hikmah dari kegagalan tersebut. Dengan kata lain, resiliensi adalah kemampuan seseorang untuk bangkit kembali dari kegagalan dan ketidakpastian sehingga orang tersebut tetap dapat positif dalam memandang hari depannya. Luthans (2015) menyatakan bahwa Modal Psikologis dapat dikembangkan dengan pemberian pelatihan dan edukasi mengenai Modal Psikologis. Peran Modal Psikologis yang meningkat diharapkan juga meningkatkan performa karyawan saat bekerja.

Menurut Eisenberger, et. al. (1986) Dukungan Organisasi adalah persepsi karyawan mengenai sejauh mana organisasi menghargai kontribusi mereka dan peduli terhadap kesejahteraan mereka. Dukungan Organisasi telah ditemukan memiliki konsekuensi penting terhadap kinerja dan 
kesejahteraan karyawan. Karyawan menghargai perusahaan yang memberikan penghargaan terhadap kontribusi kerja karyawan dan peduli akan kesehatan mental mereka. Adanya Dukungan Organisasi mengurangi tingkat ketidakhadiran. Hubungan antara Dukungan Organisasi dan tingkat absensi lebih besar dampaknya pada karyawan dengan ideologi social exchange theory.

Dukungan Organisasi meningkatkan komitmen karyawan dalam organisasi di mana karyawan berharap bahwa hasil kerjanya akan dihargai oleh perusahaan. Dukungan Organisasi dirasakan oleh karyawan melalui atasan mereka (Eisenberger, et.al., 2002). Atasan yang memberikan pujian dan persetujuan akan dianggap sebagai Dukungan Organisasi terhadap kerja keras karyawan. Penghargaan materiil seperti gaji, peringkat, dan pengayaan jabatan juga merupakan beberapa bentuk dukungan sosial yang dirasakan oleh karyawan. Neves dan Eisenberger (2012) menemukan bahwa perlakuan supervisor merupakan hal yang dilihat karyawan dalam menentukan besarnya Dukungan Organisasi. Penelitian ini juga menemukan bahwa keterbukaan komunikasi antara manajemen dan karyawan adalah cara yang efektif untuk meningkatkan kinerja karyawan.

Kurtessis, et.al. (2015) menyatakan bahwa hasil dari dukungan sosial ada 3 yakni orientasi yang positif terhadap pekerjaan dan organisasi, kesejahteraan subjektif dan perubahan perilaku. Peningkatan orientasi positif didapatkan dari meningkatnya kewajiban, kepercayaan dan harapan organisasi terhadap karyawan. Sebaliknya karyawan akan merasa pendapat dan usaha kerasnya dihargai oleh perusahaan, sehingga muncul komitmen afektif karyawan terhadap organisasi. Pada akhirnya pengalaman kerja yang menyenangkan akan meningkatkan minat karyawan terhadap pekerjaan yang dilakukan sehari-hari. Dukungan Organisasi akan turut mempengaruhi mood, emosi dan penilaian akan kepuasan kerja. Dukungan Organisasi juga turut menguatkan self efficacy, penghargaan diri sendiri berbasis organisasi dan keseimbangan antara kerja dan kehidupan keluarga. Hal ini tentu saja akan meningkatkan kesejahteraan subjektif. Dengan pemenuhan kebutuhan sosio-emosional, Dukungan Organisasi akan meningkatkan komitmen afektif karyawan terhadap perusahaan. Dukungan Organisasi akan memunculkan norma timbal balik di mana karyawan berkewajiban untuk meningkatkan performa kerja sesuai dengan arahan organisasi dan memperoleh penghargaan atas usaha keras mereka.

\section{METODE PENELITIAN}

Penelitian ini mengunakan pendekatan kuantitatif. Variabel tergantung yang diukur dalam penelitian ini adalah Kesiapan Kerja, sedangkan variabel bebasnya adalah Modal Psikologis dan Dukungan Organisasi. Data dikumpulkan dengan menyebarkan kuesioner kepada 100 orang mahasiswa Perguruan Tinggi X di Jakarta yang sedang mengikuti program internship di berbagai instansi, baik swasta maupun pemerintah.

Penelitian dilakukan di Perguruan Tinggi X yang berlokasi di Jakarta. Data dikumpulkan dengan menyebarkan kuesioner kepada mahasiswa yang sudah pernah mengikuti program internship. Kuesioner yang digunakan untuk mengukur variabel Kesiapan Kerja adalah Work Readiness Questionnaire yang dikembangkan oleh Brady. Kuesioner ini terdiri dari 18 pernyataan yang disusun berdasarkan 6 aspek Kesiapan Kerja, yaitu tanggung jawab, fleksibilitas, keterampilan, komunikasi, cara pandang terhadap diri sendiri, serta kesehatan dan keselamatan kerja. Variabel Modal Psikologis diukur dengan menggunakan Psychological Capital Questionnaire yang dikembangkan oleh Luthans. Kuesioner ini terdiri dari 12 pernyataan yang dikembangkan dari 4 konstruk Modal Psikologis, yaitu self efficacy, harapan, optimisme, dan resiliensi. Variable Dukungan Organisasi diukur dengan menggunakan Survey Perceived Organizational Support yang dikembangkan oleh Eisenberger. 


\section{HASIL PENELITIAN}

Hasil pengolahan data yang dilakukan menunjukkan bahwa Modal Psikologis memberikan kontribusi signifikan bagi Kesiapan Kerja $(F=23.435, p<0,05)$. Oleh karena itu, hipotesis Modal Psikologis berperan signifikan terhadap Kesiapan Kerja diterima. Analisis lebih lanjut memberikan hasil bahwa kontribusi yang diberikan Modal Psikologis terhadap Kesiapan Kerja adalah sebesar $34,8 \%$, sedangkan $65,2 \%$ sisanya dipengaruhi oleh faktor-faktor lain, seperti faktor demografis, motivasi, dukungan sosial dari orang terdekat, perencanaan karir, kematangan individu, dan lain-lain. Hasil pengolahan data yang dilakukan menunjukkan bahwa Dukungan Organisasi memberikan kontribusi signifikan bagi Kesiapan Kerja $(\mathrm{F}=8.979, \mathrm{p}<0,05)$. Oleh karena itu, hipotesis Dukungan Organisasi berperan signifikan terhadap Kesiapan Kerja diterima.

Selanjutnya peneliti melakukan analisis lebih jauh, dengan hasil yang menunjukkan bahwa Dukungan Organisasi memberikan kontribusi sebesar 16,9\% terhadap Kesiapan Kerja. Sisanya, yaitu sebesar $83,1 \%$, disumbangkan oleh faktor lain. Hasil analisis regresi yang dilakukan menunjukkan hasil bahwa kedua variabel memberikan kontribusi yang signifikan bagi terbentuknya Kesiapan Kerja pada mahasiswa internship ( $F=14.349, p<0,000)$. Oleh karena itu, hipotesis Modal Psikologis dan Dukungan Organisasi bersama-sama berperan signifikan terhadap Kesiapan Kerja pun diterima. Dari Analisa statistic selanjutnya disimpulkan bahwa variabel Modal Psikologis dan Dukungan Sosial bersama-sama memberikan kontribusi sebesar $40 \%$ terhadap Kesiapan Kerja. Sisanya, yaitu 60\%, dipengaruhi oleh variabel lain.

\section{Pembahasan}

Berdasarkan penjelasan di atas, dapat disimpulkan bahwa Modal Psikologis yang dimiliki oleh mahasiswa peserta program internship di Universitas $\mathrm{X}$ dan dukungan organisasi tempatnya mengikuti program internship memberikan kontribusi bagi Kesiapan Kerja mahasiswa tersebut. Semakin tinggi persepsi mereka terhadap dimilikinya Modal Psikologis dan Dukungan Organisasi, akan semakin besar pula kontribusinya terhadap Kesiapan Kerja mereka.

Dari hasil penelitian di atas dapat dilihat bahwa hubungan Modal Psikologis terhadap Kesiapan Kerja lebih besar daripada hubungan antara Dukungan Organisasi terhadap Kesiapan Kerja. Hal ini menunjukkan bahwa faktor internal yang dimiliki mahasiswa lebih banyak berperan terhadap Kesiapan Kerja mereka. Dalam hal ini, self efficacy, harapan, optimisme, dan resiliensi seorang mahasiswa berperan terhadap kesiapan mereka dalam bekerja. Self efficacy akan menentukan kepercayaan diri mahasiswa dalam menyelesaikan satu tugas ke tugas lainnya ketika bekerja. Hal ini akan terkait dengan penetapan tujuan, penerimaan akan tantangan, menyelesaikan tantangan yang sudah diambil, memiliki motivasi yang tinggi, dan tetap tekun dalam mencapai tujuan walaupun terdapat hambatan.

Harapan mahasiswa dalam bekerja merupakan motivasi positif yang secara interaktif dapat mengantarkan seseorang kepada kesuksesan oleh karena adanya dorongan dan keinginan untuk mencapai tujuan dalam bekerja. Optimisme ditandai dengan membuat atribusi positif hingga dapat meraih kesuksesan, baik di saat ini maupun di masa depan. Selanjutnya, resiliensi akan memampukan mahasiswa untuk bangkit dari kegagalan dan mengambil hikmah dari kegagalan tersebut.

Faktor eksternal yakni Dukungan Organisasi turut meningkatan komitmen karyawan dalam organisasi di mana karyawan berharap bahwa hasil kerjanya akan dihargai oleh perusahaan. Dukungan Organisasi dirasakan oleh karyawan melalui atasan mereka (Eisenberger, et.al., 2002). Atasan yang memberikan pujian dan persetujuan akan dianggap sebagai Dukungan Organisasi 
terhadap kerja keras karyawan. Penghargaan materiil seperti gaji, peringkat, dan pengayaan jabatan juga merupakan beberapa bentuk dukungan sosial yang dirasakan oleh karyawan.

Kurtessis, et.al. (2015) menyatakan bahwa terdapat tiga hasil dari dukungan sosial, yakni orientasi yang positif terhadap pekerjaan dan organisasi, kesejahteraan subjektif serta perubahan perilaku. Peningkatan orientasi positif didapatkan dari meningkatnya kewajiban, kepercayaan dan harapan organisasi terhadap karyawan. Dukungan Organisasi akan turut mempengaruhi suasana hati, emosi, dan penilaian akan kepuasan kerja. Dukungan Organisasi juga turut menguatkan self efficacy, penghargaan diri sendiri berbasis organisasi dan keseimbangan antara kerja dan kehidupan keluarga. Dengan pemenuhan kebutuhan sosio-emosional, Dukungan Organisasi akan meningkatkan komitmen afektif karyawan terhadap perusahaan.

Berdasarkan pemaparan di atas, dapat disimpulkan bahwa Modal Psikologis dan Dukungan Organisasi berperan terhadap kesiapan mahasiswa dalam bekerja. Hasil penelitian ini sejalan dengan penelitian-penelitian terdahulu yang melibatkan variabel-variabel yang sama.

\section{KESIMPULAN}

Kesimpulan yang dapat diambil dari hasil pengolahan data adalah bahwa Modal Psikologis dan Dukungan Sosial berperan secara signifikan dalam membentuk Kesiapan Kerja mahasiswa peserta program internship di Universitas X. Selanjutnya, Peneliti memiliki beberapa saran yang dapat diberikan kepada pihak-pihak terkait. Salah satu saran yang dapat diberikan kepada institusi pendidikan adalah dengan membuat program seminar berisikan edukasi mengenai Modal Psikologis dan Dukungan Organisasi yang dapat diperoleh ketika bekerja. Seminar ini diharapkan dapat menjadi bekal bagi para lulusan dalam memasuki dunia kerja nyata yang pasti berbeda dengan kondisi dalam dunia perkuliahan.

Adanya seminar ini diharapkan dapat menjadi pembekalan yang positif bagi para lulusan sehingga mereka dapat menjadi lulusan yang siap kerja dan siap pakai di dunia kerja. Salah satu hal yang dapat ditekankan dalam seminar ini adalah penekanan untuk menciptakan perasaan dan pikiran yang optimis di mana lulusan baru didukung oleh lingkungannya seperti keluarga, pihak universitas dan pihak pemberi kerja. Kondisi ini tentu saja dapat meningkatkan Modal Psikologis yang dimiliki oleh mahasiswa. Mahasiswa juga harus merasa tertantang ketika menghadapi suatu hambatan, tidak menyerah dan tetap berusaha untuk mencari penyelesaian yang terbaik ketika menghadapi berbagai tantangan dalam dunia kerja.

Dukungan organisasi bagi mahasiswa yang sedang menjalankan program internship merupakan salah satu hal yang tidak bisa dikontrol baik mahasiswa maupun pihak universitas. Yang dapat dilakukan oleh pihak universitas adalah memberikan pembekalan kepada mahasiswa mengenai dunia kerja yang tentu harus disikapi dengan cara yang berbeda dengan dunia perkuliahan. Oleh karena itulah materi mengenai Dukungan Organisasi dalam bentuk seminar ini menjadi penting dan bahkan akan lebih baik jika pihak universitas menjadikan materi edukasi ini sebagai salah satu bagian dari mata kuliah yang wajib diambil oleh para mahasiswa tingkat akhir. Dengan demikian, semua mahasiswa memperoleh paparan mengenai dunia kerja nyata dan terutama Dukungan Organisasi yang bisa mereka dapatkan dari para dosen dan juga alumni yang sudah terlebih dahulu memiliki pengalaman dalam dunia kerja.

Melalui seminar ini, mahasiswa akan memperoleh paparan informasi yang luas baik dari dosen maupun dari para alumni. Gambaran kerja yang nyata dan yang tidak hanya teoretis dapat diperoleh oleh mahasiswa melalui program ini. Dalam seminar tersebut, mahasiswa dapat memperoleh paparan informasi yang luas mengenai kasus-kasus yang ditemui selama bekerja. 
Dengan adanya seminar ini, mahasiswa pada akhirnya merasa diperhatikan dan didukung oleh orang-orang di lingkungannya. Hal ini diharapkan dapat meningkatkan modal psikologis mahasiswa dalam menjalani program internship sehingga dapat menyelesaikan program dengan baik dan pada akhirnya setelah lulus dapat menjadi pekerja profesional di dunia kerja nyata. Dengan dilaksanakannya program-program yang bertujuan untuk mengembangkan Modal Psikologis dan informasi yang mendukung mengenai Dukungan Organisasi kepada mahasiswa peserta program internship, diharapkan Kesiapan Kerja mereka pun akan meningkat, sehingga kemungkinan mereka untuk diterima sebagai karyawan pada suatu perusahaan setelah mereka lulus akan semakin besar.

\section{DAFTAR PUSTAKA}

Agusta, Y. N. (2015). Hubungan antara Orientasi Masa Depan dan Daya Juang terhadap Kesiapan Kerja pada Mahasiswa Tingkat Akhir Fakultas Ilmu Sosial dan Ilmu Politik di Universitas Mulawarman. eJournal Psikologi. 3 (1), 369-381.

Bandaranaike, S. \& Willison, J. (2015). Building capacity for work-readiness: Bridging the cognitive and affective domains. Asia-Pacific Journal of Cooperative Education, 3, 223 233.

Brady, R.P., (2010). Work Readiness Inventory. JIST Works Publishing, Indianapolis, IN.

Cabellero, C.L. \& Walker, A. (2010). Work readiness in graduate recruitment and selection: a review of current assessment methods. Journal of Teaching and Learning for Graduate Employability, 1,13-25.

Chaplin, J.P. (2011). Kamus Lengkap Psikologi. Jakarta: Rajagrafindo Persada.

Coetzee, M. (2014). Psycho-social Meta-capacities. Dynamics of contemporary career development. Heidelberg, SW: Springer.

Departemen Tenaga Kerja dan Transmigrasi. (2003). Diunduh dari http://www.kemenperin.go.id/kompetensi/ UU_13_2003.pdf, 12 Maret 2017

Eisenberger, R., Hungtington, R., Hutchison, S., \& Sowa, D. (1986). Perceived Organizational Support. Journal of Applied Psychology, 71, 500-507.

Eisenberger, R., Stinglhamber, F., Vandenberghe, C., Sucharski, I., \& Rhoades, L. (2002). Perceived supervisor support: Contributions to perceived organizational support and employee retention. Journal of Applied Psychology, 87, 565-573.

Kurtessis, J. N., Eisenberger, R. Ford, M. T. Buffardi, L. C. Stewart, K. A., \& Adis, C. S. (2015). Perceived organizational support: A meta-analytic evaluation of organizational support theory. Journal of Management, 43 (6), 1-31. DOI: 10.1177/0149206315575554

Luthans, F (2015). Organizational Behavior - An Evidence-based Approach (13th ed). Boston: McGraw Hill Inc

Mason, G. Williams, and Cranmer, S. (2009). Employability skills initiatives in higher education: what effects do they have on graduate labour market outcomes?. Education Economics, 17, $1-30$.

Neves, P., \& Eisenberger, R. (2014). Perceived organizational support and risk taking. Journal of Managerial Psychology, 29, 187-205.

Sampson, J. P., Jr., Peterson, G. W., Reardon, R. C., \& Lenz, J. G. (2000). Using readiness assessment to improve career services: A cognitive information processing approach. The Career Development Quarterly, 49, 146-174.

Saputro, N. D., \& Suseno, M. N. (2009). Hubungan antara Kepercayaan Diri dengan Employability pada Mahasiswa. Psikohumanika. 2 (1), 13-14.

Winkel S.J dan MM. Sri Hastuti. 2006. Bimbingan dan Konseling di Institusi Pendidikan. Yogyakarta : Media Abadi. 